\title{
A CASE STUDY ON LINGUISTIC MEANS OF EDITING FOR VOICE AND TONE IN CORPORATE MARKETING COMMUNICATION
}

The research analyses a small corpus of in-house writing of a multinational SME by nonnative speakers of English and the edits and revisions made by a marketing expert and a technical writer (native English speakers). The analysis focuses on identifying, classifying and analyzing edits regarding the voice and tone guidelines, i.e., how pragmatics concepts (politeness and audience accommodation) are grammatically and semantically encoded. The research uses style guides to analyze the "comparable" monolingual corpus of drafts and final versions, while the annotation includes tags for pragmatically motivated changes whose purpose is establishing a friendly relationship with the target audience. The research employs norms for qualitative research in public relations and marketing communication (Daymon \& Holloway, 2010) and shows that a) non-native speakers of English tend to have a self-centered approach to workplace English writing and often fail to achieve the company voice and tone, and b) the company voice and tone require elimination of culturally specific concepts and use of relatively simple grammatical structures and lexicon.

Key words: voice, tone, marketing communication, technical communication, revision, corporate communication, workplace English

\section{INTRODUCTION}

This study builds upon the foundation laid in previous research that sought to identify and define linguistic (e.g. pragmatical, grammatical and semantic) constraints that are used to formulate tone and voice guides of small and medium enterprises, as well as in those of large corporations (e.g. Delin 2007 and Carnevale et al 2017). For the sake of absolute terminological clarity, the phrase "tone and voice guides" is used here to refer to (usually confidential) company documents that define the corporate identity and whose integral parts are instructions on the tone, voice and style of language that should be used in all marketing and technical content that the company makes available to the general public, e.g. the language

\footnotetext{
*olgapk@ff.uns.ac.rs
} 
used on the company website, in promotional videos, social media posts, help files, user guides, etc. A publicly available voice and tone guide is, for example, the Salesforce Voice and Tone guide, shown in Figure 1. In short, these guides are, from the corporate perspective, devised with a purpose of ensuring unique projection of the company "identity" in all its outward-facing textual (and other) production. This research seeks to determine, in a small corpus, what language features and means are used to craft this textual production, so that the original proposition still fulfills its communicative intention but also fits the constraints of relevant tone and voice guidelines.

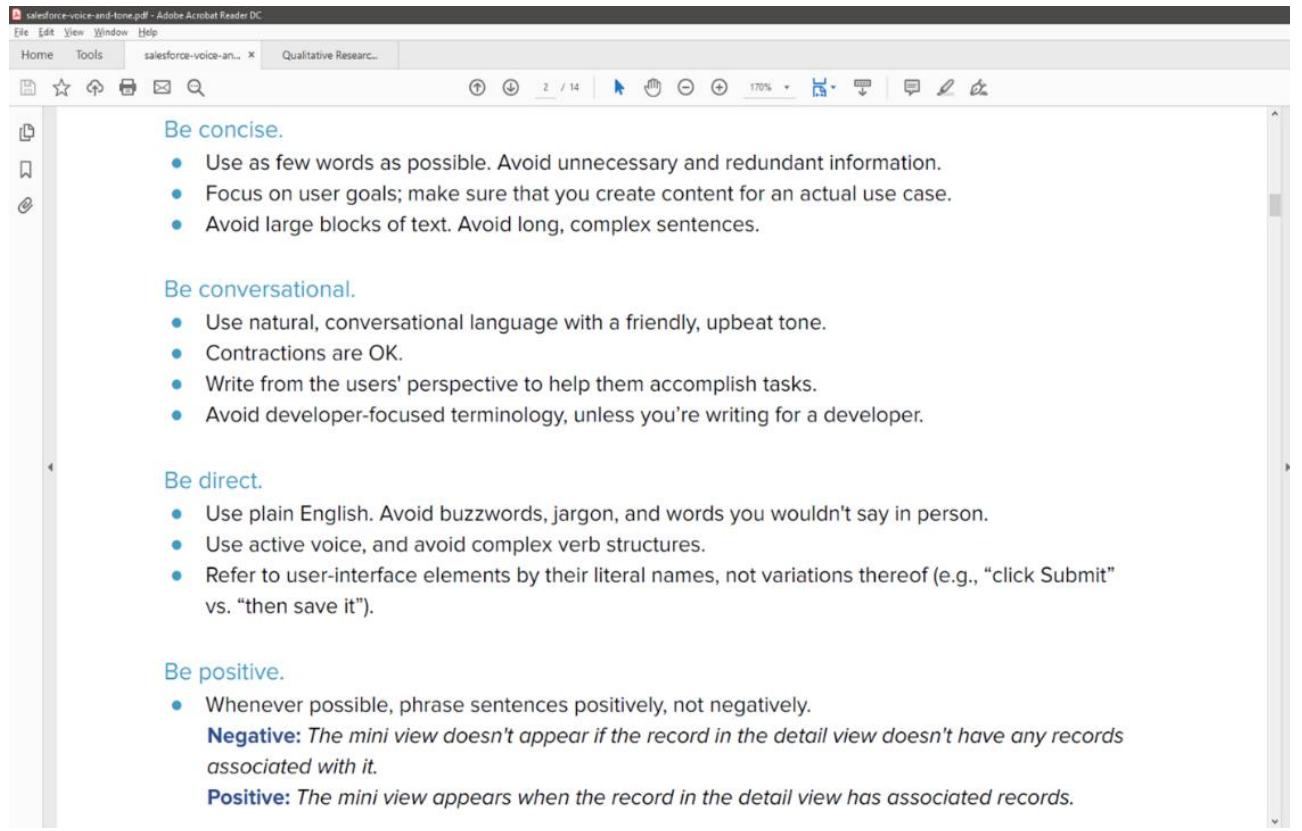

Figure 1: The Salesforce Voice and Tone Guide ${ }^{1}$ : an example of a corporate voice and tone guide

\footnotetext{
${ }^{1}$ The style guide is no longer available from the Salesforce website, but can still be found via Salesforce affiliate and partner sites, e.g from this link: https://www.lightningdesignsystem.com/assets/downloads/salesforce-voice-and-tone.pdf
} 


\section{THEORETICAL FOUNDATIONS FOR RESEARCHING LINGUISTIC ASPECTS OF VOICE AND TONE IN CORPORATE MARKETING COMMUNICATION}

Because the topic of this research is an investigation of practical applications of tone and voice as observed in edits and changes in a corpus of drafts and revised in-house writing, this introductory chapter will first define tone and voice (guidelines) from the linguistic point of view and will then proceed to establish the theoretical framework for the research.

\subsection{Defining corporate tone and voice from the linguistic point of view}

Linguistically, tone and voice guides represent a corporate, marketingoriented application of linguistic concepts of audience design and referee design. Audience design is sociolinguistic model that stipulates that style-shifting occurs primarily in response to a speaker's audience, i.e. that speakers (or writers) adjust their language towards that of their audience in order to express solidarity or create intimacy with them (Bell, 1984). Similarly, referee design describes communicative situations where the speaker (or the writer) consciously decides not to accommodate their speech style to their immediate audience, but rather "creatively uses language features ... from beyond the immediate speech community“ (Bell, 2001: 147). In other words, referee design is a shift whereby speakers decide to use styles associated with a social group or groups that are not present at the moment when the language production occurs with the hope that the chosen style will signal hypothetical allegiances with these (currently absent) speakers.

Having this in mind, the corporate marketing voice can be defined as a corporation-specific utilization of referee design to create a corporate identity by means of language structures that have strong registral connotation. Some structures that serve this purpose include direct addressing of the reader, simple lexicon and simple grammar and a conscious effort to present everything in a positive sense. It should be stressed that the corporate marketing voice, just like a person's voice, does not change and stays the same regardless of the communicative situation and the target audience. What changes depending on the communicative situation is the tone of that fixed and strictly-defined company voice.

Contrary to the corporate voice which has to do with the referee design, the corporate marketing tone may be defined as marketing-oriented utilization of audience accommodation to craft the corporate message by using language structures that will best resonate with the perceived target audience. In other words, 
the corporate tone changes depending on the target audience as represented in the marketing and sales funnel, shown in Figure 2.

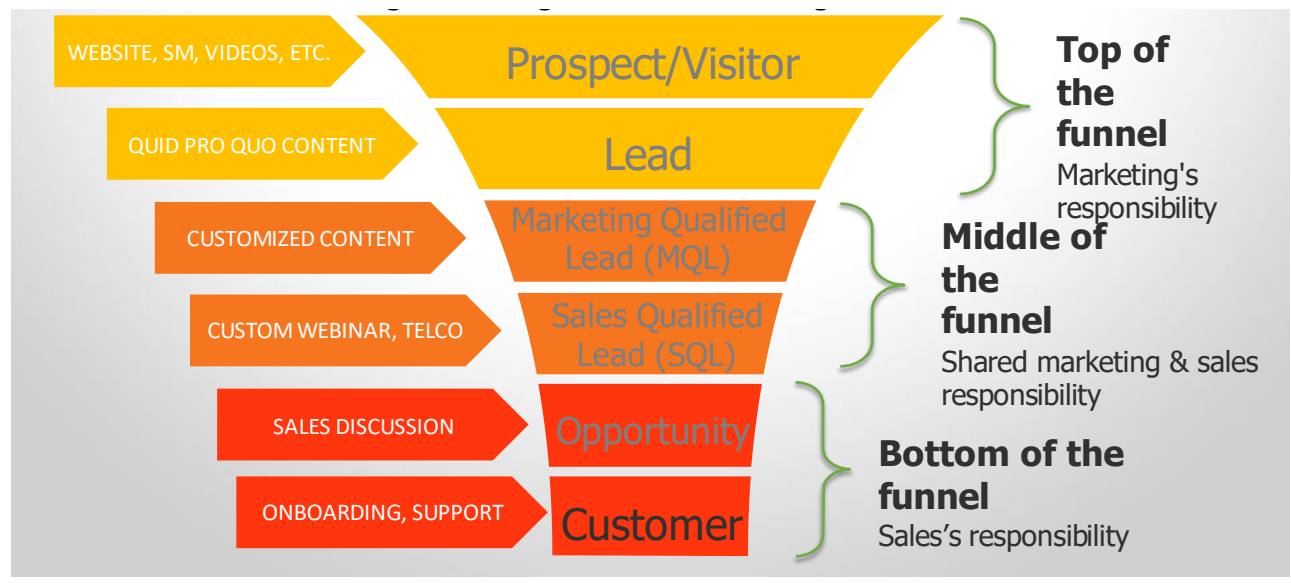

Figure 2: The marketing and sales funnel identifying the status of a prospect from the initial to the final stage of their customer/client journey: a modified version of Soldner (2019)

When analyzing the sales and marketing funnel, it becomes clear that an individual's progress along the customer journey, from a prospect to a paying customer, implies that the individual is served different types of content and that each type of content is tailor-made for the given stage of the customer journey. For example, in case of hi-tech companies, the content for the top of the marketing funnel (aimed at prospects and leads) is written so as to be as easy for laymen to read as possible and to present the benefits of the company offering in the simplest terms possible, e.g. there is no specialized terminology, sentences are short and simple, etc. This is quite different to the content written for the bottom of the funnel, which is targeted at the "initiated" soon-to-be customers and may contain heavy use of expert terminology and complex ideas in complex sentences. An example of tone guidelines used by an SME are shown in Figure 3, where it is also clear how each tone corresponds to a different stage in the marketing/sales funnel. 


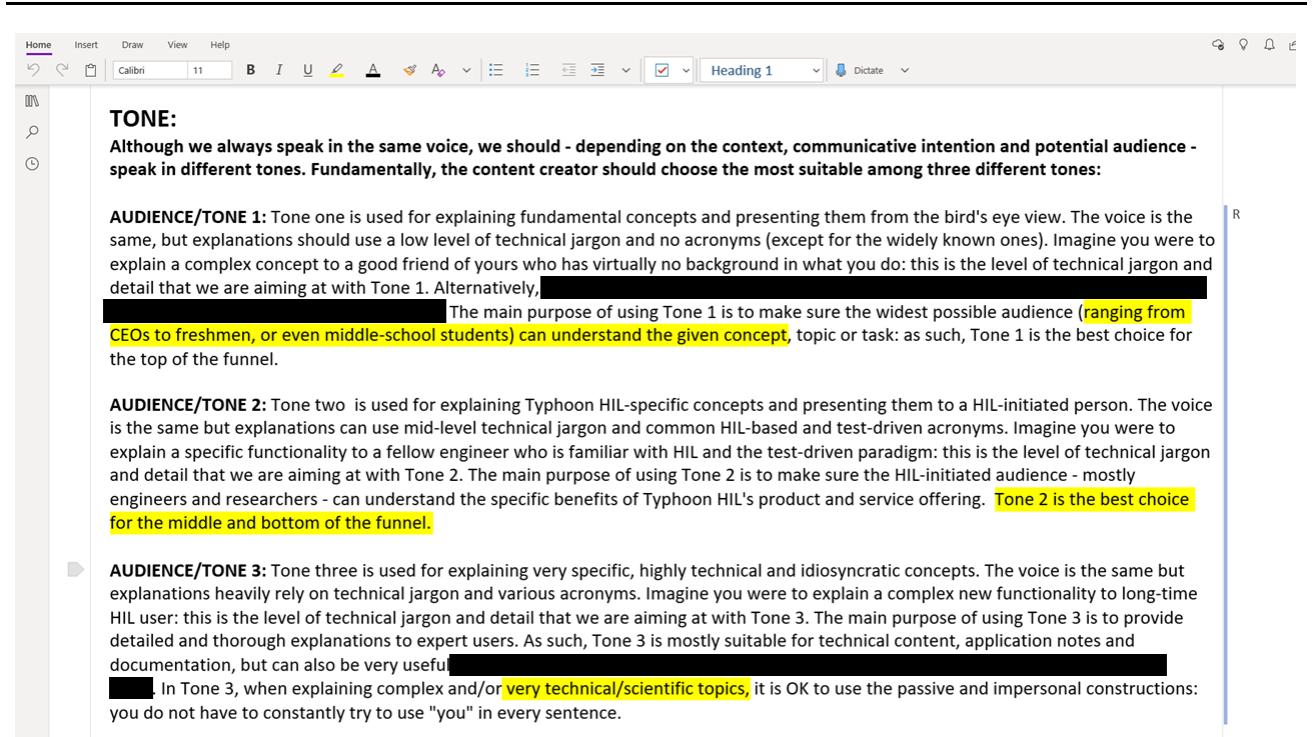

Figure 3: An example of a tone guide (courtesy of Typhoon HIL Inc.; confidential info is blacked out per their request)

In summary, the corporate voice is modulated as having different tones for different audiences, whereby some of the means of tone modulation seem to be the use of terminology and jargon, as well as simplification or full representation of concepts.

\subsection{Analyzing linguistic means of encoding tone and voice guidelines}

Once the tone and voice as underlying frameworks of marketing communication in workplace English are defined, the question poses itself: how are tone and voice encoded in public-facing textual content? In other words, what linguistic devices and means are used to shape the proposition so as to match the style and voice guidelines? This is exactly what the research set out to discover.

At this point it is important to mention that exhaustive research of scientific publications and databases failed to identify any previous studies that directly tackle the topic of how tone and voice are encoded from the linguistic points of view. The only references to tone and voice are found in discussions on workplace English and marketing communication in relationship to corporate identity. More specifically, there are a couple of studies on workplace English that briefly mention that writing documentation and manuals are important parts of workplace English which non-native speakers find particularly challenging due to corporate instructions on how to write (e.g. Kaneko et al., 2009). Similarly, there are many 
studies and books on marketing communication that discuss this form of communication as a subtype of workplace English where employees, who are mostly non-native speakers of English, must produce written or multimodal content for different sections of the funnel (web pages, blogs, white papers, custom quotes, technical support). These sources view marketing communication as having the purpose of advertising company products/services and increasing brand awareness: marketing communication is therefore not situationally and contextually defined but is strategically crafted and devised to present the company in a particular way (e.g. Stuart, 1999; Stuart \& Kerr, 1999; Tsai, 2008). In other words, everything that the customer or prospect can see and read is considered to be marketing content which serves the purpose of marketing communication: guidelines on how to craft the linguistic message can therefore be seen as one of the main instruments of corporate identity.

In summary, the desk, theory-related research on the topic only confirmed its validity and relevance, but provided no benchmarks and methodological guidelines in the form of previous studies. In this respect, this research may be said to fill the gap in the domain of analyzing the interplay of marketing-induced constraints on human language and workplace English. On the other hand, this required for the research to devise the methodology from scratch. Both the methodology and the findings of the research after the methodology was applied are presented in the next section.

\section{LINGUISTIC MEANS OF EDITING FOR VOICE AND TONE}

The central part of this paper will first present the corpus and methodology of its investigation in order to move to the main part of the study where the results of the corpus analysis are presented and linguistic means for ensuring voice and tone compliance are identified.

\subsection{The corpus and the research methodology}

Given the novelty of the research topic and the lack of previous studies that could be used as a reference or foundation, the choice of methodology was neither simple nor straightforward. The first challenge revolved around finding a corresponding corpus, while the second challenge involved devising the best methodology for analyzing the corpus. Of the two challenges, the first one was the most significant. Namely, to identify and analyze edits made for the sake of corporate voice and tone compliance, it was necessary to find a corpus where those 
edits can be observed, i.e. a corpus which shows the draft version written by engineers or copy writers and the final version which was edited by reviewers and/or technical writers. However, no such corpus is publicly available and the companies which were contacted (e.g. Microsoft, Google, Salesforce, Amazon, etc.) were not willing to provide this kind of text material. Eventually, it was the IT company Typhoon HIL Inc, with offices in Boston, Basel and Novi Sad, which agreed to provide relevant text samples for this research. At this point the researcher would therefore like to thank Typhoon HIL Inc. for allowing the use of their inhouse marketing materials for a linguistic study (made by a dozen engineers who are non-native speakers of English and edited by two native speakers of English: a marketing editor and a technical writer).

The corpus consisted of MS Word documents with tracked changes turned on, making it possible to see both the original draft and the edits. As such, the corpus used in the research could be called a specialized, monolingual English corpus of drafts and final versions, similar to an error-annotated corpus, but different in the sense that edits were not made only to fix errors, but also to fit the message to tone and voice guidelines. This type of corpus is not identified in corpus textbooks or tangentially related studies (e.g. Aijmer, 2008; Beißwenger \& Storrer, 2008; Bennett, 2010; McEnery \& Hardie, 2012) and could be called a "review monolingual corpus".

Size-wise, the corpus was rather small but can be claimed to be representative of the phenomenon being investigated as it is the only corpus, to the best knowledge of the author, that contains original drafts and edits for tone and voice. It consisted of 3 MS Word documents (123,827 words) with tracked-changes turned on: a general user manual ( 68 pages $=19,979$ words), a modeling software manual (301 pages $=96,445$ words) and four application notes $(28$ pages in total $=$ 7,403 words). Having in mind that the corpus relied on tracked-changes information contained in MS Word files, the corpus was also annotated in MS Word by means of color-coded annotation, i.e. no separate corpus analysis and annotation tool was used. All edits were published in relevant marketing channels (e.g. website, webhelp and blog posts) in the spring of 2020. A screenshot of one of the corpus files is shown in Figure 4. 


\section{Typhoon HIL Control Center}

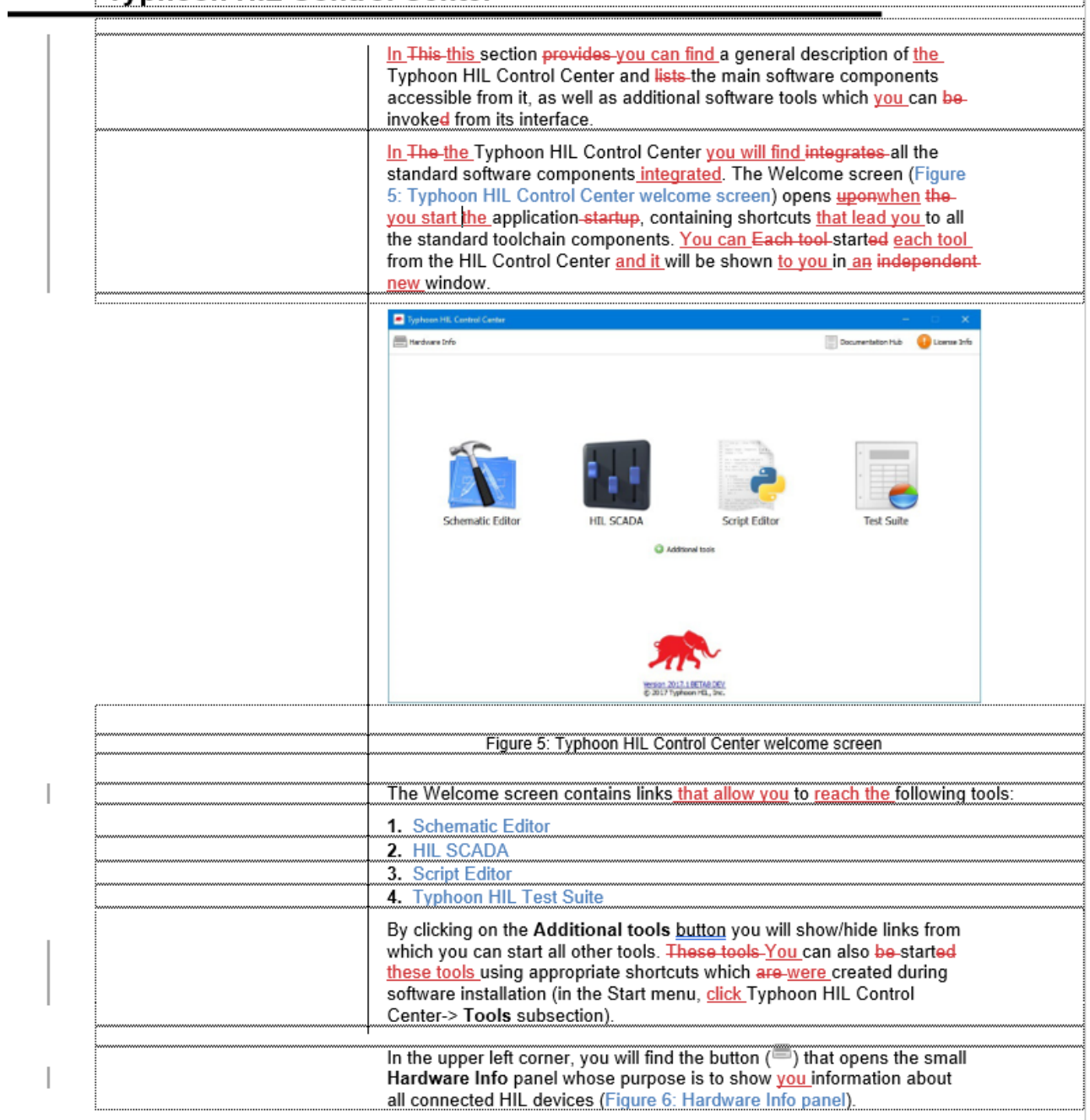

Figure 4: A corpus file example with tracked changes: all edits were analyzed, while the relevant ones were annotated as tone and voice edits

Once the corpus was compiled, the research employed norms for qualitative research in public relations and marketing communication (Daymon \& Holloway, 2010). Plainly speaking, a critical reading of the edits in the corpus was conducted in parallel with tone and voice guides: each edit was annotated as either being a correction (e.g. a missing article, wrong agreement, etc.) or as a tone/voice edit. All tone and voice edits identified in this way were then further classified based on what grammatical, lexical or pragmatical feature/means was used to adjust the message so as to match the required corporate tone and voice. The types of these 
adjustments, i.e. tone and voice edits, are exemplified and identified in the following subsections.

\subsection{Main research findings: types of linguistic edits for achieving tone and voice}

The qualitative analysis and annotation of edits in the corpus identified five distinct linguistic means used to shape the voice of the marketing content, as well as three distinct means of shaping the tone of the marketing content. Of course, these linguistic means of shaping voice and tone are differently applied in different context and there is a lot of variation on how exactly they are achieved, but they can be claimed to represent the "common linguistic denominator" of various strategies of language use employed for achieving the correct tone and voice. The first subsection (3.2.1.) presents the linguistic means of shaping the voice of the message, while the second subsection (3.2.2.) presents those used for shaping the tone.

The following sections use the following typographic rules to indicate the phenomena observed in the corpus:

bold = tone or voice edits,

italicized $=$ other edits, e.g. grammatical corrections or other voice/tone edits not related to the one being discussed.

\subsubsection{Linguistic means for shaping the voice of marketing content}

The corpus analysis identified five general means of shaping the corporate voice in a piece of marketing content. Although edits in the corpus differed in their scope and varied in terms of grammatical and/or lexical transformations which were used, the purpose of these edits could always be labeled as belonging to one of the following types:

\subsubsection{Means of shaping the corporate voice \#1: personalized addressing with explicit pronoun "you”"}

The most common means of shaping the corporate voice seems to be direct addressing of the target audience with frequent and consistent use of the secondperson singular pronoun "you". This probably stems from the company's perceived need for talking directly to the customer. It is very likely this means of creating a company voice is driven by an effort to avoid the use of "stale" impersonal style. Personalized direct addressing of the reader often requires additional changes and 
grammatical transformations in the sentence, e.g. a shift from the passive voice to the active one. This is shown in Example 1 where a long, complex sentence employing an impersonal passive construction "each tool started... will be shown" was split into two shorter active sentences with an explicit use of the pronoun "you". As indicated in the introductory section, the relevant edits in each example are written in bold letters while other edits (either grammatical edits, or tone and voice edits from a different category) are written in italics.

\section{Example 1:}

Each tool started from the HIL Control Center will be shown in independent window.

\section{$\downarrow$ REVIEWED AND EDITED AS $\downarrow$}

You can start each tool from the HIL Control Center. Every tool will appear in a new window.

\subsubsection{Means of shaping the corporate voice \#2: instructional imperative constructions}

The second most common means of shaping the corporate voice is related to the first one (direct addressing of the target audience by means of frequent and consistent use of the second-person singular pronoun "you"), but does not imply the use of explicit "you" in the subject. This strategy is labeled as "instructional imperative constructions" which, in practice i.e. in edits, implies changes from the indicative verbal mood and factual statements to the imperative mood, similar to giving somebody instructions on how to accomplish a particular task. Like the first means of shaping the corporate voice, this one probably stems from the company's perceived need to talk directly to the customer. However, in this case the ultimate goal is probably not to avoid the use of "stale" impersonal style, but, instead, to create a sense of company being helpful and showing the customer how to do and/or achieve something. This is shown in Example 2 where a sentence containing putative should is rewritten so as to use the imperative mood.

Example 2:

Execution rate of each circuit should be set in the properties window.

$\downarrow$ REVIEWED AND EDITED AS $\downarrow$

Set the execution rate of each circuit in the Properties window. 
3.2.1.3. Means of shaping the corporate voice \#3: simplify and mimic the everyday spoken language

The third means of shaping the corporate voice is labeled as "mimic the everyday spoken language" because it manifests itself in the use of contracted forms and simple, every-day lexis - i.e. the edits involve shortening the full forms of verbal construction and replacement of highly-specialized, expert terms with more common synonyms used in every-day communication. Additionally, this also often involves splitting lengthy sentences into shorter ones. This, in all probability, should not be understood as a means by which companies make an effort to sound "cool" or "funky", but, actually, as an indicator of the company's effort to sound friendly and, for lack of a better adjective, "normal". In other words, the company wants to "sound" like a "good colleague from work". The application of these means at achieving the correct company voice is shown in Example 3 where an unnecessarily complex phrase "independent window" is replaced with a more common collocation "new window", while the long form "cannot" was shortened to "can't".

Example 3:

Each tool started from the HIL Control Center will be shown in independent window. / The variable cannot be 0 .

$\downarrow$ REVIEWED AND EDITED AS $\downarrow$

You can start each tool from the HIL Control Center. Every tool will appear in $a$ new window. / The variable can't be 0 .

\subsubsection{Means of shaping the corporate voice \#4: using only the positive polarity}

The fourth means of shaping the corporate voice could also be labeled as "be positive" because it manifests itself in edits which switch the polarity of the sentence from negative to positive. This may be an indication of the company's effort to avoid any negative connotations. This is shown in Example 4 where a negative sentence is completely rewritten to express the same idea, but using no negative items.

Example 4:

Don't write comments in the same line with code.

$\downarrow$ REVIEWED AND EDITED AS $\downarrow$ 
Please use a separate line to write comments.

\subsubsection{Means of shaping the corporate voice \#5: consistent focus on the reader and their perspective}

The last general means of shaping the corporate voice is related to means $\# 1$ and \#2, but is different in the sense that it involves a complete re-framing of the proposition. In practice, this means that all features and functions of the product (or service) are not represented as an achievement of the company or something that the company can boast about: instead, everything is presented as something that the company is doing for the user. This may be an indication of the company's effort to present itself as friendly and helpful. This is shown in Example 5 where a sentence about the company's achievement was re-written so as to explain the benefits of a new feature to the user.

\section{Example 5:}

We have introduced a new feature in Signal processing which allows the toolbox to import ANSI C code blocks.

\section{$\downarrow$ REVIEWED AND EDITED AS $\downarrow$}

You have a new feature in the Signal Processing Toolbox which allows you to import ANSI C code blocks.

\subsubsection{Linguistic means for shaping the tone of marketing content}

In contrast to the five means of shaping the corporate voice in marketing content, the corpus analysis identified fewer general linguistic means of shaping the tone: only three. The same disclaimer used in section 3.2.1. can be used here - the tone edits in the corpus differed in their scope and varied in terms of grammatical and/or lexical transformations which were used, but the purpose of these edits could always be labeled as belonging to one of the following three overarching means of achieving the right tone of the message.

\subsubsection{Means of shaping the corporate tone \#1: varying degrees of assumed knowledge}

Perhaps the most important means of achieving the correct tone is assuming different degrees of knowledge. Just like in everyday communication one would not use the same tone of voice to discuss e.g. the rules of proper behavior with toddlers 
and experts, the corporate tone of voice has to match the perceived level of readers' knowledge at a given stage of their customer journey. The most common way of achieving this is by varying the level of detailed explanation in the text: in the topof-the-funnel content every concept deemed as potentially new is described in details (assuming no knowledge), while for the bottom-of-the-funnel the text is saturated with hypernyms and highly specialized notions that assume the reader possesses expert knowledge. This can be seen in Example 6 where there is no explanation of what SunSpec represents in the text aimed at experts (application notes), while the introductory chapters of the user manual contain a detailed explanation of what SunSpec is because it is assumed that these sections may be read by complete beginners.

Example 6:

Introductory chapters: ...you can also connect via SunSpec, which represents a standardized set of monitoring and control registers based on MODBUS TCP/IP and is maintained by the SunSpec Alliance.

In an application note: .... another way to connect is via SunSpec.

\subsubsection{Means of shaping the corporate tone \#2: varying use of terminology}

The continuum between using plain language and expert terminology depending on the perceived target readers may be seen as a subtype of varying degrees of language complexity for different levels of assumed knowledge. However, while means \#1 relies on either using short, digested explanations or going into details, this means of shaping the tone of message is only about terminology. This is clearly shown in Example 7, where the introductory chapters list all current models of HIL emulators and their capabilities, while the user guide uses the hypernym "HIL emulator" which assumes that the reader knows which models are currently available and what their specs are.

Example 7:

Introductory chapters: .... be connected to a HIL402, HIL604 or another Typhoon HIL FPGA-powered, high-fidelity, real-time emulator which allows the power stage emulation at a 500-ns time step.

In the communication protocol user guide: ... without a HIL emulator. 


\subsubsection{Means of shaping the corporate tone \#3: varying the use of jargon}

Varying degrees of jargon use should not to be confused with varying use of terminology, because, unlike terminology, jargon is both technical terminology and a specific set of idiomatic expressions used for a specific activity or by a specific group (whereas terminology is a set of special words in a particular field). This is best shown in Example 8 which compares the first segment from Example 7, but contrasts it with a phrase "on a HIL" found in a highly specialized manual. "A HIL" is classified as jargon, because "HIL" normally represent the name of testing methodology (Hardware In the Loop), while the same acronym preceded by an article represents a jargon term used by HIL experts to refer to "a HIL device".

Example 8:

Introductory chapters: .... be connected to a HIL402, HIL604 or another Typhoon HIL FPGA-powered, high-fidelity, real-time emulator which allows the power stage emulation at a 500-ns time step.

In the SCADA manual: ...running on a HIL.

\subsubsection{Basic descriptive statistics}

The corpus contained a total of 8255 segments, and they have been analyzed and annotated in accordance with the methodology described in 3.2.1. A segment refers to a sentence or a sentence fragment (e.g. a title, caption, etc.) beginning in a capital letter and ending in ., :, ;, ! or ? (or in a paragraph mark, i.e. new line). As shown in Table 1, close to 60\% (58.97\%) of segments in the corpus contained at least one tone or voice edit which can be taken as a clear indication that in-house content creators using workplace English have certain issues following the tone and voice guidelines. This statement is further reinforced by the fact that segments containing voice and tone edits usually contain more than one tone and voice edit: there are 1.71 voice and tone edits per segment for a total of 8305 edits, as shown in Tables 1 and 2. This table also presents the break-down of the main types of edits in terms of lexical or grammatical interventions, which will be the focus of a future research.

\begin{tabular}{|lr|}
\hline Total segments in the corpus: & $\mathbf{8 2 5 5}$ \\
\hline Segments containing an edit & 4868 \\
\hline Number of segments with an edit & 58.97 \\
\hline Number of edits per segment & 1.71 \\
\hline
\end{tabular}

Table 1: General frequency of tone and voice edits in the corpus 
Type of a tone/voice edit: Occurences:

\begin{tabular}{r|r} 
Splitting of sentences & 301 \\
Passive to active voice & 2812 \\
\cline { 2 - 2 } Impersonal to personal (including “you") & 3692 \\
Terminology change & 674 \\
\cline { 2 - 2 } Grammar/lexicon simplification & 826 \\
\cline { 2 - 2 } TOTAL EDITS FOR TONE AND VOICE: & $\mathbf{8 3 0 5}$
\end{tabular}

Table 2: Types of tone and voice edits in the corpus and their frequency

Table 2 shows that the most common types of edits are those that enable switching from impersonal style to the personal style of directly addressing the reader and the switch to the active voice. Terminology changes and grammar/lexicon simplifications are much less frequent, while the least frequent means of achieving the tone and voice is splitting of sentences.

\section{CONCLUDING REMARKS}

The corpus analysis of edits used for achieving corporate tone and voice compliance identified a total of 8 general means of shaping the message to have the required tone and voice: 5 for voice and 3 for tones. The five means of achieving the correct voice are:

- personalized addressing with explicit pronoun "you",

- instructional imperative constructions,

- simplifying and mimicking the everyday spoken language,

- using only the positive polarity, and

- consistent focusing on the reader and their perspective.

On the other hand, the three means of shaping the message to fit the corporate tone include:

- varying degrees of assumed knowledge,

- varying use of terminology, and

- varying use of jargon. 
In addition to identifying these means of shaping tone and voice, the corpus analysis also identified five grammatical and lexical transformations to achieve the required tone and voice:

- splitting of complex sentences into simple ones,

- passive to active voice transformation,

- transformation of impersonal to personal constructions (often with explicit pronoun "you"),

- changes in the level of terminology use, and

- simplification of grammar and lexicon.

Finally, descriptive statistical analysis of the annotated corpus can be used to formulate two conclusions on the implementation of the corporate marketing voice and tone in the workplace:

- non-native speakers of English tend to have a self-centered approach to workplace English writing and often fail to achieve the company voice and tone, and

- the company voice and tone often require the elimination of culturally specific concepts and the use of relatively simple grammatical structures and lexicon.

It should also be stressed that these findings are based on a preliminary analysis of a very small corpus and need verification on a much larger corpus, which, together with a more detailed analysis of grammatical and lexical transformation used to shape the tone and voice, represent the key direction for further research and better verification of its findings. On the other hand, it should also be emphasized that obtaining a larger representative corpus may present a significant challenge because there are very few companies willing to share their inhouse tone and voice guides in pair with drafts and revisions of marketing content ${ }^{2}$.

${ }^{2}$ Having in mind the challenges of compiling a representative corpus for this kind of research, the author would like to, once more, thank Typhoon HIL Inc. for providing the text samples for compiling the corpus used in this research. 
Aleksandar Kavgić

\section{СТУДИЈА СЛУЧАЈА О ЈЕЗИЧКИМ СРЕДСТВИМА КОРИШЋЕНИМ ЗА УРЕЂИВАЮЕ ГЛАСА И ТОНА КОРПОРАТИВНЕ МАРКЕТИНШКЕ КОМУНИКАЦИЈЕ}

Сажетак

Ово истраживање бави се анализом малог корпуса интерно написаних маркетиншких текстова у једном малом до средњем мултинационалном предузећу. Текстови су били написани од стране запослених којима енглески језик није матерњи, док су измене и допуне текстова обавили маркетиншки стручњак и писац техничке струке који су изворни говорници енглеског језика. Анализа се фокусирала на идентификовање, класификовање и анализу измена у вези са корпоративним смерницама за постизање компанијског гласа и тона, односно на начине на који су прагматички концепти (учтивост и прилагођавање циљној публици) граматички и семантички примењени на измене у тексту. Истраживање је било базирано на корпоративном водичу за писање, који је коришћен као кључ за анализу „упоредивог“ једнојезичног корпуса који се састојао из иницијалних и коначних верзија текстова: овај корпус етикетиран је ознакама за прагматички мотивисане промене чија је сврха била успостављање пријатељског односа са циљном публиком. У истраживању су такође коришћене норме за квалитативно истраживање односа с јавношћу и маркетиншке комуникације (Daymon \& Holloway, 2010). Истраживање показује да а) постоји пет општих принципа постизања гласа (употреба простих реченица, активног глаголског начина, директно обраћање читаоцу, различити степени употребе терминологије и поједностављивање синтаксе и лексике), б) три општа принципа постизања тона (промена степена подразумеваног предзнања, промена степена употребе терминологије и промена степена употребе жаргона), в) аутори текстова којима енглески није матерњи језик исказују тенденцију ка ауто-центричном приступ писању на енглеском на радном месту и често не успевају да постигну тражени глас и тон компаније, и г) глас и тон компаније захтевају уклањање културно-специфичних концепата и употребу релативно једноставних граматичких структура и лексике.

Кључне речи: тон корпоративне комуникације, глас корпоративне комуникације, маркетиншка комуникација, техничка комуникација, уређивање текста, корпоративна комуникација, енглески језик на радном месту 


\section{SOURCES}

Salesforce Voice and Tone Guide. Retrieved on September 1, 2020 from https://www.lightningdesignsystem.com/assets/downloads/salesforcevoice-and-tone.pdf

\section{REFERENCES}

Aijmer, K. (2008). Parallel and comparable corpora. In A. Lüdeling \& M. Kytö (Eds.), Corpus Linguistics: An International Handbook (Vol. 1, pp. 275292). Berlin: De Gruyter Mouton.

Beißwenger, M., \& Storrer, A. (2008). Corpora of computer-mediated communication. In A. Lüdeling \& M. Kytö (Eds.), Corpus Linguistics: An International Handbook (Vol. 1, pp. 292-309). Berlin: De Gruyter Mouton. http://www.degruyter.com/view/product/19320

Bell, A. (1984). Language style as audience design. Language in Society, 13(2), 145-204.

Bell, A. (2001). Back in style: Reworking audience design. In P. Eckert \& J. R. Rickford (Eds.), Style and sociolinguistic variation (pp. 139-169). Cambridge: Cambridge University Press.

Bennett, G. (2010). Using Corpora in the Language Learning Classroom: Corpus Linguistics for Teachers. East Lansing, MI: University of Michigan Press/ELT.

Carnevale, M., Luna, D., \& Lerman, D. (2017). Brand linguistics: A theory-driven framework for the study of language in branding. International Journal of Research in Marketing, 34(2), 572-591.

Daymon, C., \& Holloway, I. (2010). Qualitative research methods in public relations and marketing communications. Oxfordshire: Routledge.

Delin, J. (2007). Brand tone of voice. Journal of Applied Linguistics and Professional Practice, 2(1), 1-44.

Kaneko, E., Rozycki, W., \& Orr, T. (2009). Survey of workplace English needs among computer science graduates. In: Smith, J (2009). 2009 IEEE International Professional Communication Conference. Piscataway, N.J. : IEEE. 1-6. https://doi.org/10.1109/IPCC.2009.5208704

McEnery, T., \& Hardie, A. (2012). Corpus linguistics: Method, theory and practice. Cambridge: Cambridge University Press. 
Soldner, D. (2019). Everything is Inbound: Sales. Available at https://www.vye.agency/blog/everything-is-inbound-sales (2019, November 14)

Stuart, H. (1999). Towards a definitive model of the corporate identity management process. Corporate Communications: An International Journal, 4(4), 200207.

Stuart, H., \& Kerr, G. (1999). Marketing communication and corporate identity: Are they integrated? Journal of Marketing Communications, 5(4), 169-179.

Tsai, S. (2008). Corporate marketing management and corporate-identity building. Marketing Intelligence \& Planning, 26(6), 621-633. 
